\title{
A Suggested Model for the Measurement of the Impact of Political Risk on Direct Foreign Investment: A General Framework
}

\author{
WaHid HAMZa Hashim and ABDUllah NASEER \\ Faculty of Economics and Administration \\ King Abdul-Aaziz University, Jeddah, Saudi Arabia
}

\begin{abstract}
Foreign Direct Investment has become an important subject in the field of international economy in general and public policy in particular. The high political risks involved in any foreign direct investment has also become a main concern for policy analysts as well as policy makers. Therefore, this research has attempted to construct an analytical-quantitative model that enables researchers in the fields of political science and business administration, in an interdisciplinary efforts, to measure the political risks involved in any foreign direct investment.

The. research's independent variable is political risk and is operationalized using three major instruments. The first instrument focuses on the distinction between risk and uncertainty as developed by Hanedel, West, and Meadow (1977) or in Taylor and Jodice (1983), and is called Political System Stability Index. The second instrument is based on the absence of domestic and civil conflict and violent behavior as can be found in Feierabend and Feierabend (1966) or in Taylor and Jodice (1983). The third instrument can be found in Gurr and Ruttenberg's (1967) theory and model on the condition of civil violence.

The dependent variable is the annual average foreign flow of investment for each targeted countries' chosen by any researcher. The data collected by researchers could then be analyzed using quantitative methods, such as Pearson Product Moment Correlation, in order to determine the relationship between the level of foreign direct investment flows and the degree of political risk for all subsequent years-for the sample of countries chosen-that has to be at least five or more countries. Therefore, future works, using this model are highly recommended in order to test the validity and the applicability of the model.
\end{abstract}




\section{Research Problem}

The year 1959, just before the Cuban revolution, marked the beginning of new investment from the United States to Latin America which accounted for some \$338 million. In 1960, this figure dropped substantially to $\$ 95$ million. Two years later, 1962, net flows were almost zero. ${ }^{(1)}$ Part of this dramatic change could be attributed to fluctuating exchange rates and different investment strategies, but the foreign investors in general and Americans in particular were unsatisfied and fearful of wide spread political turmoil engulfing almost all the Latin American region seemed to be a major factor in reducing investment flow and activities from abroad (the U.S.A.). Conversely, after 1974, China has become a major recipient of foreign direct investment from the U.S.A. after years of political and ideological shifts. Furthermore, after 1980, U.S. direct foreign investment flows toward the Middle East, particularly Egypt and Israel, continued to be strong if not on the increase despite the ubiquitous turbulent political risk plaguing the region.

Latin America, China and the Middle East are only three examples of a wide range of similar cases, where irregular political events produced quite different effects on foreign direct investment flows. These contradictory examples raise questions as to the effect of political environment factors decisions to invest in countries. The purpose of this research paper (proposed model) is to construct an empirical model that can measure the relationship between political risk and the outflow of foreign direct investment funds from any investing countries such as Saudi Arabia, Kuwait, or the United States of America. Future or other works could use this general framework to substitute these countries.

\section{Literature Review}

In addition to the capital evaluation of investment projects in foreign environment which places emphasis on: (1) the financial risk to be incurred in the project and (2) the amount of profit after foreign taxes, there is also a category of study dealing with determinants of foreign direct investment. This category is composed of two distinct sets of analysis, one focuses on interviews with foreign investment decision makers, whereas the other centers on cross-national empirical investigations.

Survey of managerial assessment and evaluation of the political environment reveal an interesting contrast. With few exceptions, international managers and foreign investors rate political stability as one of the major influences on the foreign investment decisions. However, the evidence indicates the absence of any formal systematic analysis of political environments and their impact on investment.

Basi, in an extensive mail survey of more than 300 international business executives, attempted to determine the criteria they used when making decisions on foreign investment. He found that a nation's level of political instability and the extent of market potential where the most significant factors in foreign investment decisions ${ }^{(2)}$. Aharoni

(1) D. Handle, G.T. West and R.G. Meadow, Overseas Investment and Political Risk. Philadelphia: Foreign Policy Research Institute, 1975.

(2) R. S. Basi, Determinants of United States Private Direct Investment in Foreign Countries, Kent: Kent University Press, 1963. 
obtained similar results via in-depth interviews with international personnel from thirtyeight firms to determine the criteria utilized in foreign investment decisions. Aharoni's findings, suggest a nation must manifest a minimum market and a certain level of political and economic stability before it is regarded as a possible investment site ${ }^{(3)}$. His second conclusion described the assessment process. "Risk is not described in terms of impact on specific investment. It is, rather, described in general terms and stems in ignorance, generalization, projection of U.S. culture and standards of other countries and on unqualified deduction from some general indicator to a specific investment" ${ }^{(4)}$ Unfortunately, as we shall see later in the research, this condition persist today.

A 1967-1968 Conference Board survey of investors in twelve countries confirmed earlier findings. First, political factors were regarded as important determinants of foreign investment by international executives and a common response to perceived political risk is avoidance of that nation as an investment site. Second estimates of political risk are typically based upon subjective perception or on information that is incomplete, outdated and in some cases even fallacious.

In two distinct studies, Root surveyed executives in a large number of U.S. firms selected from the Fortune 500 list. His findings indicated that even though international executives rated political risk and market opportunity as "the dominant factors in most investment decisions... no executives offered any evidence of a systematic evaluation of political risks, involving their identification, their likely incidence, and their specific consequences for company operations"(5). Thus it appears that executives subjective perceptions of political instability influence their attitudes toward the viability and profitability of potential investment environments.

Piper found that political factors in general tend to be treated with the same lack of concern in the foreign environment as they are in the domestic. Rather, investment appraisals tend to emphasize financial and domestic variables while ignoring political factors ${ }^{(6)}$. Bennet and Green concluded that "either foreign investors apply a superficial assessment procedure when measuring the political environment or perhaps the entire investment process is uncoordinated" ${ }^{(7)}$.

The more recent studies reported are also consistent with previous findings. In two Conference Board Report, La Palombara and Blank concluded that "while some form of political and environment assessment exists in most firms, it is usually loose and causal, placing major reliance on a subjective feeling for the political situation" ${ }^{(8)}$. Their studies reviewed various planning materials and documents purporting to assess political factors. They concluded that "More often than not, the few paragraphs devoted to a host country's social and political dynamics is not better than one might find in a leading parent country newspapers" ${ }^{(9)}$.

(3) Y. Aharoni, The Foreign Investment Decision Process, Boston: Harvard University, 1966, p.94.

(5) F. R. Root, Attitudes of American Executives Toward Foreign Investment Opportunities. Economic and Business Bulletin, 18, 1968, pp. 14-23.

F. R. Root, U.S. Business Abroad and Political Risk. MSU Business Topics, 15, 1968, pp.73-80. (6) J. R. Piper, How U.S. Firms Evaluate Foreign Investment Opportunities. MSU Business Topics, 18, 1971,

(7) P. D. Bennet and R. T. Green, Political Instability as Determinant of Direct Foreign Investment in Marketing. Journal of Marketing Research, 11, 1972, pp.182-186.

(8) J. La Palombara and S. Blank, Multinational Corporations and National Elites: A Study in Tensions. New York: The Conference Board, I976.

(9) J. La PaIombara and S. Blank, Multinational Corporations in Comparative Perspective. New York: The Conference Board, 1977, p. 65. 
The findings reviewed here are remarkably consistent. First, managers consider political instability or political risk to be an important aspect in the foreign investment decision. Second, systematic assessment and appraisal of the political environment is not the norm. Most political analysis is superficial, subjective, and integrated into the decision-making process on a very limited and informal basis.

On the other hand, a number of studies that attempt to analyze the relationship between foreign direct investment and political environment factors are inconsistent with some minor exceptions.

In 1972, Bannet and Green regressed stocks of United States foreign direct investment and trade of an index of political stability while controlling for gross national product per capita across 46 nations. They concluded that "political stability did not affect the overall movement of U.S. marketing foreign direct investment" ${ }^{(10)}$.

Green and Cunningham found measures of market potential to be the most significant predictor of U.S. foreign direct investment. From their study on 25 nations, political stability appears to be an important factor, although not significant enough to override opportunities provided by a large market potential ${ }^{(11)}$. However, the validity of this finding is questionable since their sample included both developed and developing countries. Most of the literature states foreign investors regard developed nations as politically stable; and as a result, their inclusion may mask fundamental facets of the existing relationship between political stability and foreign direct investment.

In a 62 nation study, Kobrin analyzed the relationship between flow of U.S. manufacturing foreign direct investment and political, social, and economic factors. Economic factors accounted for $64 \%$ of the variance of foreign direct investment, with market size, growth and a measure of U.S. export involvement exhibiting significant correlations $^{(12)}$.

There have been exceptions to the overall pattern results. Green and Smith formulated a weak but statistically significant relationship between profitability of U.S. foreign. direct investment and political stability. However, a methodological problem clouds interpretation of the results. Specifically, the generalizability of the study is tenuous due to the static nature of the dependent variable-1965 per capita U.S. marketing foreign direct investment ${ }^{(13)}$. In his study of oligopolistic reaction, Knicker bocker found a significant relationship between a measure of entry concentration and an index of political stability across 21 countries. He concluded that "oligopolist were not inclined to make defensive investments in unstable markets" ${ }^{(14)}$.

(10) Ibid., p.167.

(11) R. T. Green and W. H. Cunningham, The Determinant of U.S. Foreign Investment: An Empirical Examination. Management International Review, 6, 1972, pp. 23-29.

(12) S. Kobrin, The Environmental Determinants of Foreign Direct Manufacturing Investment: An Expost Empirical Analysis. Journal of International Business Studies, 1976, pp. 29-42.

(13) Ibid, p.93.

(14) F. T. Knickerbocker, Oligopolistic Reaction and Multinational Enterprise. Boston: Harvard University, 1973, p.184. 
At least two studies suggest an intricate and indirect relationship between foreign direct investment and political instability, Thurnell, attempted to analyze the relationship between major trend changes in the flow of foreign direct investment and a number of indicators of elite and mass stability. Thurnell observed an asymmetrical relationship in which a high level of mass violence precedes negative trend changes, whereas it takes both a low level of violence and a government transfer to generate a positive change. It would appear that "companies are inclined to invest in nations characterized by low level of political unrest, whereas high levels of mass political violence results in decreased investment flows" ${ }^{(15)}$

In a study of 48 countries Kobrin found a significant relationship between flows of foreign direct investment controlled for market-related factors and one dimension of domestic conflict: focused antiregime violence. The relationship observed intensifies at higher levels of development and when host country administration is strong. $\mathrm{He}$ concluded that "political conflict has the highest probability of influencing foreign investors when it is not of the degree to influence relevant changes in government policy toward foreign investment" ${ }^{(16)}$.

Root and Ahmed employed discriminative analysis to attempt to account for differences between three groups of countries based upon per capita inflows of nonextractive foreign direct investment. Only one political factor emerged as a significant discriminator: the frequency of regular executive transfers failed to discriminate over the shorter period of 1960-1967. Its explanatory powers therefore appear weak" ${ }^{(17)}$.

Thus, while it appears that political. factors are not first order determinant of foreign direct investment, they nonetheless are a major concern to actual investors. However, there are few developed techniques for assessing the political environment and/or evaluating its impact on a foreign investment.

In examining the relationship between political risk and the flow of foreign direct investment to countries under consideration, for example; Egypt, Israel, Jordan, Nigeria, Colombia, and Sudan,-during a five-year period or more - the researchers are to be prepared to avoid the shortcomings of all the statistical studies summarized. Basically, they all focus upon instability when it is clear that political instability is neither a necessary nor sufficient condition for changes in policy relevant to foreign investment.

(15) L. H. Thurnell, Political Risk in international Business. New York: Praeger Publisher, 1977.

(16) S. Kobrin, When Does Political Notability Result in Increased Investment Risk?. Columbia Journal of World Business, 13, 1978, pp. 113-121

(17) F. R. Root and A. A. Ahmed, Empirical Determinants of Manufacturing Direct Foreign Investment in Developing Countries. Economic Development and Cultural Change, 28, 1979, pp. 53-71. 


\section{Independent Variable}

\section{Operational Definition}

Although the term "political risk" is observed frequently in international business literature, its meaning primarily addresses the unwanted consequences of political action(s). It can be manifested in two models: (1) political action, for example politicosocio instability and/or aggressive behavior, and (2) government interference and constraint on operations, such as discriminatory taxation, unilateral revision of contract terms, and the confiscation of foreign-owned business property. Robock suggests the following operational definition: "... political risk in international business exists (1) when discontinuities occur in the business environment, (2) when they are difficult to anticipate and (3) when they result in political change. To constitute a risk these changes in the business environment must have the potential for significantly affecting the profit or other goals of a particular enterprise" ${ }^{(18)}$.

The concept of discontinuity and direct effect on the firm are instrumental to Robock's definition. While "discontinuities" in a particular political system may occur, they are not always sufficient to constitute political risk. Rather, due to the dynamic nature of political environments, frequent and unexpected changes in governments, parties, and/or leaders or changes in a gradual progressive fashion do not necessarily constitute political risk. For instance, a coup d'etat may simply be the accepted method for the removal of the ruling elites in the absence of mature political institutions and may have no direct relationship to the government's economic policies" ${ }^{(19)}$.

Robock's differentiation between political stability and political risk is as follows: "... political fluctuations which do not change the business environment do not represent risk for international business ... political instability, depending on how it is defined, is a separate although related Phenomena from that of political risk" ${ }^{20)}$. This distinction makes one wonder whether there is any cause to consider the political environment separately in an attempt to distinguish between sources of business risk. Nonetheless, there appears to be very realistic reasons for doing so. Although economics and politics are distinct, both as abstract phenomenon and in terms of impact on the firm, they are intricately interrelated. First politics, at least initially, largely determines the acceptable framework for economic activity. For example, the change in Cuban regime in 1959 resulted in a polar shift from a free market to a socialist economy. In the same vein, political power concerns often influence official economic policy. Although the converse is equally true - the production and distribution of wealth is a prime determinant of power - a distinction does exist and can be applied in practicality. For example, a strike motivated be dissatisfaction over work-related issues should not be automatically considered a political issue. But widespread strikes in Nicaragua in 1968 protesting the Somoza regime were of a clear political motivation.

(18) S. H. Robock, Political Risk: Identification and Assessment. Columbia Journal of World Business, 4, 1971, p. 7.

(19) Ibid., p.19.

(20) Ibid., p.8. 
Three instruments will be used to measure political risk The first approach, developed by Hanedel, West and Meadow, focuses on a distinction between risk and uncertainty - between the probability of an unwanted political event occurring and the uncertainty resulting from insufficient information about the political environment tendencies. Thus, political risk as defined by Hanedel, West, and Meadow is "the risk or probability of occurrences of some political event(s) that will change the prospects for the profitability of a given investment" ${ }^{(21)}$.

A second approach to political risk can be found in Feierabend and Feierabend and is based on the absence of domestic and civil conflict and violent behavior. A stable nation is viewed as having a peaceful, law-abiding populance in which decision making and politico-socio changes are the result of accepted institutionalized procedures and are not the outcomes of a nomic processes using conflict and aggression to resolve issues. The index developed by Feierabend and Feierabend is used to reflect this view of political stability. Conceptually they define political instability as "the degree or the amount of aggression directed by individuals or groups within the political system against other groups or against the complex of officeholders and individuals and groups associated with them"(22). In reality they equate political instability with aggressive politically relevant behavior manifest in strike, riots, coup d'etat, civil war etc.

A third approach to political risk can be found in Gurr and Ruttenberg's theory and model on the condition of civil violence. It seems logical to presume that civil violence with mass participation is: symptomatic of structural deficiencies in the political, social, and economic institutions. In all probability, this turmoil would fuel political unrest contributing to a hostile politico-socio environment dissuading foreign investment. This instrument implicitly assume "that frustration induced anger is the common denominator of participants in acts of civil violence, that anger is the principle characteristics distinguishing them from participants in other forms of collective behavior, and that it constitutes a drive that disposes them to the general character of their behavior, namely violent attacks on those they hold responsible for their frustration"(23).

In an effort to accurately measure political risk the above three instruments were selected for their similarity as well as diversity. All are indicators of political risk but each has a different conceptual origin. The Haendel, West and Meadow (1977) instrument was developed for economic-financial utility, the Feierabend and Feierabend (1966) measure for political analysis utility and the Gurr and Ruttenberg (1967) index for social psychology analysis. In addition, both the Feierabend and Feierabend (1966) and the Gurr and Ruttenberg (1967) instruments have had factor analysis applied to ascertain the stability of the constructs employed for political instability and civil violence examination.

(21) Ibid., p. 11

(22) I. K. Feierabend and R. L. Feierabend. Aggressive Behavior in Politics: "A Cross-national Study". Journal of Conflict Resolution, 10, 1966, p. 250.

(23) T. Gurr and C. Ruttenberg, The Condition of Civil Violence: First Tests of a Causal Model. Princeton: Princeton University Centre for International Study, 1976, p. 187. 


\section{Research Instruments}

The independent variable, political risk, is to be measured by utilizing three different quantitative indices. The first, instrument is the Political System Stability Index, developed by Haendel, West, and Meadow (1977), measures political risk and is believed free of attitude and opinion inputs. The Political System Stability Index is composed of 15 discrete indicators of the System's stability and is divided into three sub-indices: socio-economic, societal conflict, and governmental processes. A score and an estimate of confidence in that score (one to five) are provided for the overall index and each of the three major sub-indices. Appendix 1 contains a detailed description of the component indicators of the instrument.

Each of the three sub-indices is also given a confidence estimate, on a scale from one to five as follows:

1. Very high confidence in the accuracy, reliability and comparability of the score to those of other nations.

2. High confidence in the accuracy and reliability of the score.

3. Moderate confidence in the accuracy and reliability of the score.

4. Low confidence in the accuracy and reliability of the score.

5. Minimal confidence in the accuracy and reliability of the score.

The second instrument measures the political stability, developed by Feierabend and Feierabend in 1966, is based on the number and intensity of political activities of a nation. They have isolated thirty types of political events to which they have assigned various weights. A three-digit political instability score is calculated for each nation in the sample, which may range from 0:00 to 6:99. The first digit represent the weight attached to the most destabilizing event occurring within the nation over the time period being examined (see Appendix 2). The remaining two digits represents the sum of the weights, up to 99 , assigned to each of the destabilizing events occurring within the nation over the time period. Thus, these digits determine a nation's relative position within each of the scaler positions. The implicit assumption, therefore, is that a nation is only as stable as its most destabilizing event.

The third instrument, formulated by Gurr and Ruttenberg (1967), is an index of civil violence composed of five Basic Measures of civil violence and four Composite Scales of amount of civil violence. Each Composite Scale is an ordinal scale derived by weighted combination of two or more of the Basic Measure ordinal scales (see Appendix 3 and Appendix 4). In turn, each of the Basic Measure relates to the concept operationally defined by the corresponding Composite Scale.

\section{Dependent Variable}

The annual average foreign flow of investment for each of the developing countries in the sample, or in any other sample chosen by a researcher, functions as the dependent variable. These data are available from The Balance of Payment Year book of the International Monetary Fund (1978-1987), which records annual changes in foreign direct investment for a large number of countries. The financial data, used by the International Monetary Fund to estimate changes in foreign direct investment, are to be primarily 
collected from countries' annual income statements and balance sheets, income tax, and reports to governments in connection with currency exchange control regulation. Other data are also available in U.S. overseas loans and grants and assistance.

Several problems are expected to encounter researchers with the utilization of the data. First, most of the data entries are shown in the United States dollars, however, some are in local countries; currency transformations will be in accordance with international monetary exchange rates. A second problem may stem from the nationalization and expropriation of foreign assets which are commonly reported as negative flows of foreign investment. Such occurrences are aberrations and must be discounted from the aggregate investment flows. Third, due to the urinomas variation of international financial disclosure practices, estimates of changes in foreign direct investment might not be truly comparable from nation to nation. For instance, Middle Eastern and European firms tend to have earnings and reveal less about the monetary values of their investment flows than is common in the United States. Consequently, systematic variation is inherent in the financial data, but these variations are to be assumed to be consistent over time.

Investment flow data in comparison with other viable choice - stock of direct investment or number of foreign subsidiaries established - may be chosen as the most appropriate for the analysis regarding each country at the researchers' hand. Specifically, stock of direct foreign investment has some glaring deficiencies. First, information is not available on specific time period of accumulation for pre- 1967 investment stock so to compare it with the period of 1978 and onward.

Investment flows, despite a slight loss of precision due to the measurement procedure, have certain characteristics which are very functional. They represent the annual change of foreign direct Investment, plus they are available for long range and specific time periods.

\section{Hypotheses}

1. Ho: There is a positive relationship between the level of foreign direct investment and its degree of political risk.

Ha: There is a negative relationship or no relationship between the level of foreign direct investment and the degree of political stability.

2. Ho: There is a negative relationship or no relationship between the three instruments used to assess political risk.

Ha: There is a positive relationship between the three instruments used to assess political stability. 


\section{Sample}

\section{Methodology}

The sample to be studied in this research or in any other researches could be composed of at least five countries, for example: Egypt, Israel, Jordan, Colombia, and Sudan. However, the sample size is subject to increase or decrease according to the availability of data and the interest of the researcher. Countries that are to be chosen for research purposes should be evaluated on the basis of three major criteria: (1) each country selected is supposed to be generally considered a developing nation. (2) The sample countries could be geographically dispersed representing three continents -South America, Asia (Middle East) and Africa. (3) An attempt is to be made by the researchers to have consistency in their selections of countries. Research Strategy and Design.

Data required for each instrument are to be collected for the countries over at least a five year period in order to detect real changes in these countries' political stability. Therefore, we suggest that data are to be collected from 1970 up to the present day. Political Risk, as measured by each of the three instruments should be correlated with foreign direct investment flows for all subsequent years for the five or more countries selected (see Appendix 5). The relationship between the level of foreign direct investment and the degree of political risk (hypothesis one) are also to be tested by regressing foreign direct investment on political risk (or by any other valid statistical methods). Pearson Product Moment Correlation between the three measurement indices should be computed in order to examine the convergent validity between the three instruments (hypothesis Tow).

\section{Vulnerabilities of Design}

The most serious vulnerability that a sort of this kind of a research design may suffer from is the systematic variance due to economic considerations inherent in the investment process. A weariness of this phenomena by the researchers is crucial for appropriate interpretation of the study's results. A second probable flaw could be the limited generalizability that may result if the sample size is small. However, homogeneous nations. (in terms of development status) from a heterogeneous areas of the world could be selected as an attempt to compensate.

In addition the reliability and validity of any of these kinds of studies' findings may be questioned due to the use of occasionally imprecise data. For instance, the world press does not report all political events. The smaller and less obvious an event, the more remote its locate, the less likely to be covered by world media. However, the political significance of such events appear dubious.

Lastly, the historical nature of the data to be collected by the researchers, if an attempt is made to analyze earlier periods, might bring into question the relevance of their results. Unfortunately, the existing data for the period 1980-1988 is not quite sufficient and therefore it needs careful evaluation. Still, the purpose of this research is not to predict the future, but to construct a model for the measurement of the political risks involved in foreign direct investments decisions. 


\section{Summary, Conclusion, and Recommendations}

Direct foreign investments have become a major issue in the international political economy. The periodical waves of instability and revolutions that have struck many Third World developing countries since their political independence, in the years that followed World War II, have become a major concern for policy makers in both the private and the public sectors in rich countries. Billions of dollars were either nationalized or lost in these revolutionary processes, therefore it is important if not imperative to study this phenomena empirically and to find empirical methods that could, on the one hand, measure countries' political stability and thus assess decision makers whether or not to invest in these countries. On the other hand, it is also important to design an empirical-quantitative model that can predict countries political stability and thus can provide decision makers with some political risk measures to guide their foreign direct investment policies in Third World or in any other countries.

Accordingly, and stemming from the absence of such a measure and such a model, we have suggested an empirical "Model for the Measurement of the Impact of Political Risk on Foreign Direct Investment in Third World countries". This model could be utilized by researchers to determine the extent to which a country, or countries, can make foreign direct investment safely. The suggested research's problem is to examine the relationship between political risk and the outflow of foreign direct investment, from any investing rich country to any Third World countries.

The validity of the model could be tested by various scholars when applied to various countries, however, the model has been designed to be applicable to various cases regardless of any ideological orientation and without any political or economic connotation. The mode1 is intended to provide the researchers in social science with a new empirical tool that guide them in their social inquiry.

In the process of developing this model, a survey of the literature that have been done on the subject, was evaluated in order to lay down a concrete analytical structure for the model. Second, the research hypotheses were stated and related to the main problem, and research vulnerabilities were identified to promote awareness and to avoid bias and subjectivity. Third, we have found that while it appears that political factors are not first order determinant of foreign direct investment, they nonetheless are a major concern to actual investors.

Future researches on this subject are to test this model and to apply it to foreign direct investments in Third World countries. Data are available in the three instruments mentioned above in the research and also can be gathered, for updated information, from: the New York Times Index, The World Bank Report, and from the World Handbook for Political and Social Indicators (Taylor and Jodice 1983).

Furthermore, the countries' sample size is to be at least five or more countries to facilitate comparison and to find general results and findings that can be deduced from to similar cases. Lastly, statistical analyses, such as Pearson Product Moment Correlation, are to be applied to the data collected in order to examine the convergent validity of the three instruments utilized in the research. 
Instability and revolutions that marked the second part of the twentieth century in various parts of the Third World countries may hinder economic development and growth in both developing and developed countries. Thus a safe and secure investments are highly dependent upon making a wise decision, which is also highly dependent upon measuring the political risks involved in each investment. Accordingly, the Political Risk Model suggested herein, could be useful for both foreign policy makers as well as for business decision makers, which could be utilized by both, or by each of them, to carefully evaluate future investments in Third World countries.

\section{References}

Aharoni, Y., The Foreign Investment Decision Process, Boston, Harvard University, 1966.

Basi, R. S., Determinants of United States Private Direct Investment in Foreign Countries. Kent: Kent University Press, 1963.

Bennet, P. D. and Green, R.T., Political Instability as Determinant of Direct Foreign Investment in Marketing, Journal of Marketing Research, 11, 1972, 182-186.

Feierabend, I. K. and Feierabend, R. L., Aggressive Behavior in Politics: A cross-national study, Journal of Conflict Resolution, 10, 1966, 249-271.

Green, R. T., Political Instability as a Determinant of U.S. Foreign Investment. Austin: University of Texas, 1972.

Green, R. T. and Cunningham, W. H., The Determinant of U.S. Foreign Investment: An Empirical Examination. Management International Review, 6, 1972, 23-29.

Gurr, T. and Ruttenberg C., The Condition of Civil Violence: First Tests of a Causal Model. Princeton: Princeton University Centre for International Study, 1976.

Heandel, D., West,. G.T. and Meadow, R. G., Overseas Investment and Political Risk. Philadelphia: Foreign Policy Research Institute, 1975.

Knickerbocker, F. T., Oligopolistic Reaction and Multinational Enterprise. Boston: Harvard University, .1973.

Kobrin, S., The Environmental Determinants of Foreign Direct Manufacturing Investment: An expost Empirical Analysis. Journal of International Business Studies, 1976, $29-42$.

Kobrin, S., When Does Political Notability Result in Increased Investment Risk? Columbia Journal of World Business, 13,1978,113-121.

La Palombara, J. and Blank, S., Multinational Corporations and National Elites: A Study in Tensions. New York: The Conference Board, 1976. , Multinational Corporations in Comparative Perspective. New York, The Conference Board, 1977.

National Industrial Conference Board. Obstacles and Incentives to Private Foreign Investment, 19671968, Volume 1: Obstacles. New York National Industrial Conference Board: New York, 1969.

Piper, J. R., How U.S. Firms Evaluate Foreign Investment Opportunities. MSU Business Topics, 18, 1971, 11-20.

Robock, S. H., Political Risk: Identification and Assessment. Columbia Journal of World Business, 4,. 1971, 6-20.

Root, F. R., Attitudes of American Executives Towards Foreign Investment Opportunities. Economic and Business Bulletin, 18, 1968, 14-23. , U.S. Business Abroad and Political Risks. MSU Business Topics, 15, 1968,73-80.

Root, F. R. and Ahmed, A. A., Empirical Determinants of Manufacturing Direct Foreign Investment in Developing Countries. Economic Development and Cultural Change, 28, 1978, 53-71.

Taylor, Charles and Jodice, David, World Handbook of Political and Social Indicators. Third Edition: Yale University Press, New Haven and London, 1983.

Thurnell, L. H., Political Risk in International Business. New York: Praeger Publisher, 1977.

World Bank Report, World Development Indicators, New York, U.N. Publications (data are available from the 1940s to the present year 1988. Years used in the research are: from 1960 to 1987$)$. 


\section{Appendix (1) \\ Political System Stability Index}

\section{Socio-economic Characteristics Index}

A. Ethnolinguistic Fractionalization: (The Atlas Narodov Mira Index). based on Country's ethnic and linguistic heterogeneity, (is used).

B. Percentage Growth in Per Capita National Product. This measure indicates a developing nation's ability to satisfy the economic demands of its citizenry as well as the ability of the political system to provide a political climate favorable to economic expansion.

C. Percentage Growth in Per Capita Energy Consumption. This measure indicates a developing nation's ability to satisfy the economic demands of its citizenry and serves as a predictor of the future since growth leads to additional growth.

\section{Societal Conflict Index}

A. Public Unrest Index. These three indicators reflect public dissatisfaction and thus provide an estimate of the pressure for change in the political system.

1. Number of demonstrations. (A demonstration is a peaceful gathering of at least 100 people for the primary purpose of displaying opposition to government policies or authority).

2. Number of riots. (A riot is a demonstration involving the use of force and resulting in material damage or bloodshed).

3. Number of governmental crisis. (A Government Crisis is a rapidly developing situation that threatens to bring about the immediate downfall of the government).

B. Internal Violence Index. The four indicators for this index reflect opposition to the means by which conflicting values are resolved within a society, rather than just opposition to some particular policy.

1. Number of armed attacks. (An armed attack is an act of violent political conflict carried out by an organized group to destroy the power exercised by another organized group).

2. Number of assassinations. (An assassination is the political motivated murder of a high government official or politician).

3. Number of coup d'etat. (A coup d'etat is an attempt of the armed forces or policy or by members of the ruling elite to overthrow the central government by force or by threat of force.

4. Number of guerilla warfare incidents. (Such as incidents in activity by bands of citizens or irregular forces aimed at overthrow of the existing government).

C. Coercion Potential Index. This index measures the capability to punish certain forms of behaviour and to reinforce others.

1. Number of internal security forces per thousand persons of the working age population. The size of the force reflects calculations of the number needed to maintain order.

\section{Governmental Processes Index}

A. Political Competition Index. The index is derived from variables that measure the competitiveness of the nominating process, the presence of legislative coalitions, their legislative effectiveness, and the degree of party legitimacy.

B. Legislative Effectiveness. Effectiveness is coded as follows:

1. No legislature: 0 points

2. "Rubber Stamp" legislature: 1 point

3. Executive power outweighs legislative: $\quad 2$ points

4. Legislature has significant autonomy: 3 points

C. Number of Constitutional Changes Per Year. Frequent changes indicate lack of fundamental agreement on the political "rules of the game."

D. Number of Irregular Executive Changes.. A change refers to the transfer of the national executive's office outside of the conventional legal or customary procedure.

Source: From Overseas Investment and Political Risk, D. Haendel, G. West and R. Meadow. Philadelphia: Foreign Policy Research Institute, Monograph Series Number 21,1975. 


\section{Appendix (2)}

\section{Political Instability Events}

0 - Institutionally Prescribed Elections. This Category encompasses all national popular elections.

1 - Fall of Cabinet. When the entire cabinet resigns or is dismissed it is considered a fall of the cabinet.

2 - Martial Law. This category encompasses the suspension of the Constitution or some of its portion and its replacement by military rule. The action must be politically motivated and not in response to a natural disaster.

3- Assassination of Significant Group Leaders. Assassination is defined as the politically motivated murder or attempted murder of politically significant figures by a group or individuals not acting under governmental authority. (Executions are expected from this definition as are murders or attempted murders for non-political reasons. Similarly, terrorism and combat casualties are excluded.

4- Arrests. Arrests are defined as the governmental seizure or detainment of individuals for political reasons. (This category includes imprisonment or jailing. It is limited to politically motivated arrests and excludes arrests for non-political reasons).

5- Coup d'etat. It is defined as an illegal or forceful attempt to change the top governmental office holders whether successful or not.

6- Civil war. This category involves an all-out war between two or more organized major segments of the population. Each segment has its own government and the entire nation becomes implicated.

Source: From "Aggressive Behaviour in Politics: A Cross-national Study," I.K. Feierabend and R.L. Feierabend, Journal of Conflict Resolution, 1966, 10, 249-271.

\section{Appendix (3)}

\section{Basic Measures}

Basic Measure One: Number of Participants. Participants are all reported to have been members of the group(s) engaging in violence, excluding the punitive forces opposing them. Police. army and other regime personnel are counted if acting in a capacity other than that of agent of the regime; of the year.

Basic Measure Two: Social Area. The extent of the polity affected by the mbsi widespread strife event

Basic Measure Three: Number of Casualties. This is the total number of deaths and injuries reported as direct consequences of civil violence.

Basic Measure Four: Property Damage: This measure, having no direct relationship to monetary value, is intended to reflect the amount of damage relative to the scope of action indicated by preceding Basic Measure.

Basic Measure Five: Duration. The total amount of time encompassed by all occurrences of civil violence during any one calendar year.

Source: From "The Conditions of Civil Violence: First Test of Causal Model" By T. R. Gurr and C. Ruttenberg, Research Monograph 28 (April), 1967. Princeton University Centre of International Studies.

\section{Appendix (4)}

\section{Composite Scale}

Composite Scale One: Pervasiveness. This scale combines Basic Measure One, Number of Participants. and Basic Measure Two. Area. to obtain a measure of the extent to which civil violence is diffused throughout the nation.

Composite Scale Two: Intensity. This scale combines Basic Measure Three, Number of Casualties, and Basic Measure Four, Property Damage to index the relative degree of violence resulting from civil strife. Composite Scale Three: Amplitude. This scale combines Pervasiveness and Intensity by equal weighing.

Composite Scale Four: Magnitude of Civil Violence. This scale is the final weighted combination of all Basic Measures.

Source: From "The Conditions of Civil Violence: First Test of A Causal Model" by JR. Gurr and C. Ruttenberg, Research Monograph 28 (April), 1967. Princeton: Princeton University Centre of International Study. 
Appendix (5)

\section{Date Collection Matrix}

1978

1979

980

1981

1982

1983

Columbia pssi, FDI

F\&F,FDI

G\&R,FDI

Egypt

Israel

Jordan

Nigeria

Sudan

$\mathrm{r} \quad=$ Pearson Product Moment Correlation

FDI = Foreign Direct Investment.

PSSI = Political Stability Index.

$\mathrm{F} \& \mathrm{~F}=$ Feicrabend and Feierabend Political Instability Index

$\mathrm{G} \& \mathrm{R}=$ Gurr and Ruttenberg Civil Violence Index. 


\section{نموذج مقتزح لتأثير المخاطر السياسية على الاستثمارات الحنارجية المباشرة \\ وحيد حمزة هاشم و عبدالله نصير

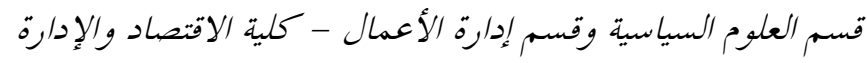

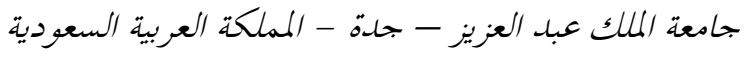

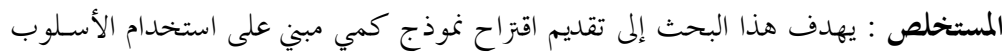

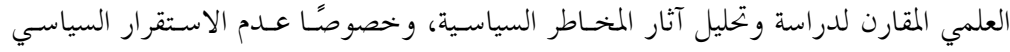

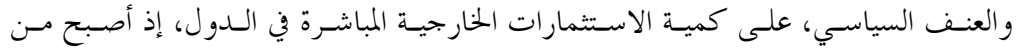

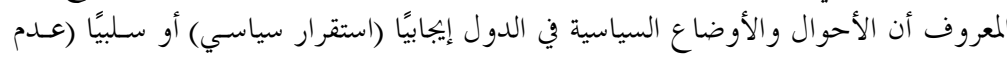

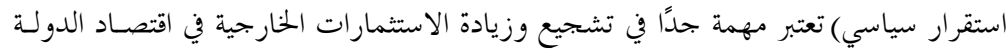

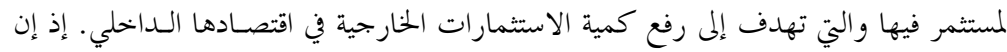

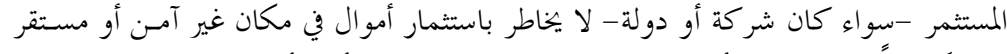
سياسيًا خوفا من فقدانه لرأس ماله سواء كان ذلكان لكان بالتخريب أو التأميم.

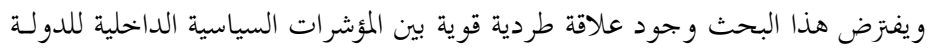

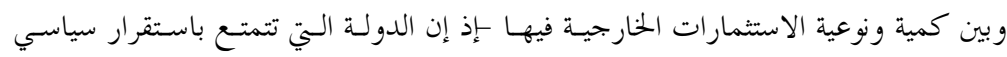

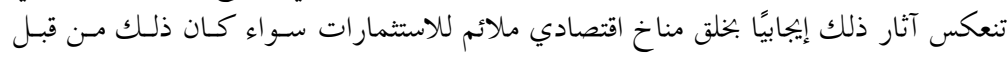

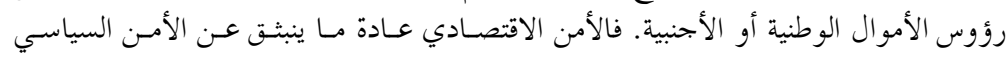

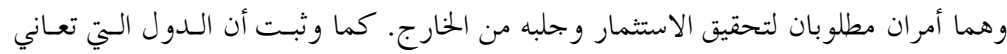

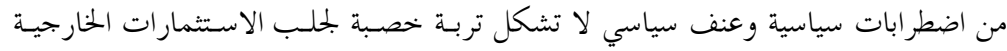

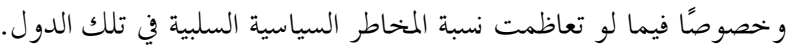

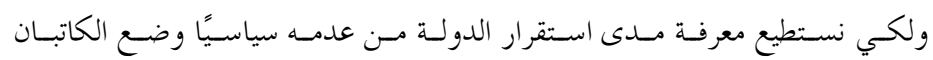

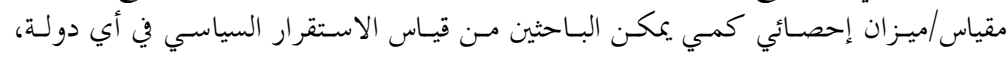

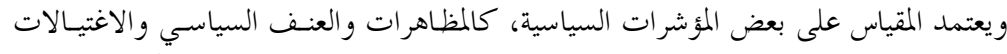

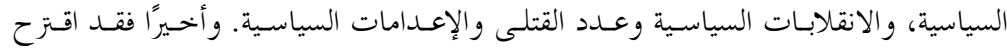

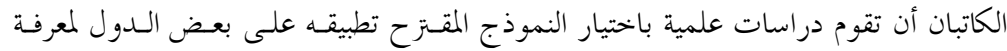

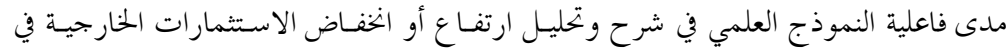

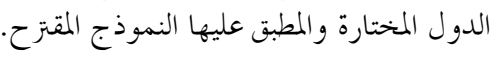

